\title{
EL ARZOBISPO FONTE Y LA INTRODUCCION DE LA VACUNA EN LA HUASTECA MEXICANA
}

\section{Dimas Fernández-Galiano}

La figura del Arzobispo Fonte es muy poco conocida en México, y lo mismo sucede en España, a pesar de que en los últimos años han aparecido aquí hasta cuatro artículos sobre esta atractiva personalidad (1).

El interés que puede ofrecer a los mexicanos el Arzobispo Fonte, el último Arzobispo de nacionalidad española de la Archidiócesis mexicana, procede de su intervención en la vida y en la política de México durante los años 1815 y .1823, años decisivos en los que se está gestando y al fin se establece la independencia de esta nación. .

Sin embargo, por lo que lo traemos:aquí a colación es por haber sido en 1820 el introductor de la vacuna antivariólica en una vasta región de México, contribuyendo así decisivamente al mejoramiento de la salud de sus habitantes, como se ha de ver más adelante.

$$
\text { 米洸 }
$$

Pedro José Fonte Hernández nació el 13 de marzo de 1777 .en Linares de Mora, bellísimo pueblo rodeado de montañas, a unos 80 kilómetros de Teruel, capitál de su diócesis.

El joven Fonte realizó sus estudios sacerdotales hasta 1801 en el Sèminario de la Archidiócesis de Zaragoza, pero al mismo tiempo cursó con no- 
table aprovechamiento en esta capital estudios de Filosofía Moral y de Economía Civil y Política, doctorándose finalmente en Derecho Civil y en Derecho Canónico en la Universidad zaragozana. En ésta conoció y trabó amistad con un paisano suyo, éste de Villel, localidad a 17 kilómetros de Teruel, Tadeo Calomarde, quien con el tiempo llegaría a ser todopoderoso Ministro del rey Fernando VII. Quiero resaltar sus estudios civiles, que nos muestran un espíritu inquieto y culto, que no se conformaba simplemente con los estudios eclesiásticos, sino que los ampliaba y perfeccionaba formándose en disciplinas y materias políticas y sociales.

En 1801 Fonte, ordenado de sacerdote y habiendo obtenido una plaza de canónigo de la catedral de Teruel, se incorpora al cabildo catedralicio de su diócesis natal, regido por entonces por el obispo D. Francisco Javier Lizana y Beamont, riojano de Logroño y hombre de gran valía.

El obispo Lizana le acogió con gran cordialidad, asignándole varios cargos en el gobierno de la diócesis, que desempeñó Fonte con gran competencia y lealtad hacia su obispo.

Tan buenas dotes mostró el joven canónigo, que cuando en 1802 fue nombrado Lizana para la silla metropolitana de México, se llevó con él a América al joven Fonte como familiar y le nombró provisor y vicario general de la archidiócesis mexicana, es decir, como un auténtico hombre de confianza.

Fonte se embarcó, pues, para Veracruz, a donde llegó el 16 de diciembre de 1803 y a la capital mexicana a mediados de enero de 1804, tomando posesión de sus cargos el día 17 y empezando en esa fecha su andadura mexicana, que había de durar 19 años, hasta el 20 de febrero de 1823, fecha en la que se hizo a la mar para su definitivo regreso a España.

Durante los diez años de su permanencia junto al arzobispo Lizana y hasta el fallecimiento de éste el 12 de septiembre de 1812, se ocupó Fonte con diligencia en sus cargos eclesiásticos (entre los cuales, el de párroco de la Iglesia del Sagrario, de la capital mexicana), pero no por ello descuidó sus actividades intelectuales, pues desempeñó (por cierto, sin' percibir sueldo alguno) durante el curso 1805-1806, la cátedra de Disciplina Eclesiástica en la Universidad de México y, debido a sus méritos e inteligencia, fue elegido académico de la Real Academia de San Carlos de Nueva España.

A la muerte de Lizana, desaparecido su máximo valedor en América, se aprestó Fonte para su regreso a España y, con el pretexto de visitar a su septuagenaria madre, solicitó de la Regencia de España (2).y obtuvo de ésta a finales de 1813 una licencia de dos años para pasar a España, viaje que 
inició en octubre de 1814 incorporado a un convoy (3) protegido por el ejército, ya que en aquellas fechas; encendida ya la insurrección, el camino de México a Veracruz era frecuentemente interceptado por los insurgentes. En estas condiciones de inseguridad, no es de extrañar que él tuviera que detenerse por más de cuatro meses en Jalapa, donde, con varios cajones de correspondencia detenida en Veracruz, le llegó un pliego de España en el que el Ministro Universal de Indias le comunicaba que S. M. le había nombrado en 3 de marzo de 1815, arzobispo de México.

El nombramiento sorprendió sobremanera a Fonte, pues esta silla metropolitana estaba ya ocupada por don Antonio Bergosa, obispo de Oaxaca, que había sucedido a Lizana por decreto de la Regencia, y no faltaba ya para su consagración más que se recibieran las correspondientes bulas papales. Pero es sabido que Fernando VII, al regreso de su cautiverio en Valençay, dictó el 4 de mayo de 1814 el «Manifiesto de Valencia», por el que anulaba todas las disposiciones de la referida Regencia. Una de ellas fue la referente al nombramiento de Bergosa, a quien se ordenaba restituirse a Oaxaca en el mismo documento en que se nombraba a Fonte para arzobispo de México.

Algunos autores han querido ver en este nombramiento la mano de Calomarde, amigo de Fonte y con quien estaba en frecuente relación epistolar (4), pero existen varios indicios que desmienten esta suposición: en las memorias del arzobispo (de las que se hablará luego más detalladamente) dice éste que por entonces (con el resto de la correspondencia llegada a Jalapa) recibió una carta de Calomarde comunicándole la decisión de S. M. de nombrarle arzobispo de México y en la que le ofreció «la lisonjera esperanza de que pronto regresaría a España a ocupar otra silla episcopal», lo que, evidentemente, era más del gusto de Fonte que continuar en una Nueva España tan revuelta por la insurrección independentista (5). Además, se conoce y está publicada (6) una carta del Ministro Universal de las Indias, don Miguel de Lardiazábal, a Fernando VII en que dice explícitamente que Fonte estaba propuesto por la Cámara de Indias para obispo de Valladolid de Micoacan (hoy Morelia), y que él (Lardiazábal) había propuesto a S. M. que Fonte fuera nombrado arzobispo porque creía "ser el hombre que conviene en Méjico en las circunstancias actuales» y "por el juicio que yo tenía formado de él desde que fue Regente», y también que "de lo cual nada supo Calomarde hasta que yo bajé del despacho y se encontró con Fonte, arzobispo de Méjico, cuando él lo esperaba Obispo de Valladolid». 
Me he detenido un tanto en el relato de las peculiares circunstancias de su nombramiento para mostrar que no fue la ambición de honores o de poder lo que llevó a Fonte a una edad relativamente tan temprana (estaba a punto de cumplir los 38 años) a una tan alta posición en la Nueva España, sino sus indudables méritos.

De ellos, en efecto, hizo gala durante los ocho años siguientes, durante los que fue, bastante a su pesar, la segunda figura, después del Virrey, entre las Autoridades de México y gobernó la archidiócesis más importante y extensa de la .Nueva España, con nada menos que nueve diócesis sufragáneas, a saber, las de Puebla, Yucatán, Oaxaca, Michoacán, Chiapas, Durango, Guadalajara, Nuevo León y Sonora.

No fueron, sin embargo, unos años placenteros los que le tocó vivir a Fonte al frente de la silla metropolitana. A las ya de por sí arduas y complicadas tareas que suponía la administración de tan extenso territorio, se añadía la peculiar situación histórica. Desgarrada España por la invasión napoléonica y por las actitudes revolucionarias de muchos de los patriotas, y levantada en el Virreinato la insurrección independentistạ, los acontecimientos sacudieron a Fonte, que se halló frente a una situación cambiantè en la que las actitudes de unos y otros eran a veces imprevisibles. Lo más importante para él era conservar la cabeza clara y salvar la firmeza y là dignidad de su autoridad. Fonte era profundamente españolista y muy respetuoso y leal hacia España y hacia la dinastía borbónica, todo ello sin detrimento de su sentido religiośo y de su fidelidad a su rey y al Papa, y puede suponerse la preocupación con que veía a su rey cautivo y en el destierro, contemplaba tambalearse la soberanía de España en América, percibía el aflorar de poderosas actitudes ánticlericales en la península y se percataba de la escisión ideológica de su clero, la mayoría del cual simpatizaba más o menos claramente con los que para él eran simplemente unos insurgentes.

Ilustrativas de este estado de ánimo son sus relaciones con Itúrbide en 1822, cuando los sucesos que llevaron a la formal proclamación de la independencia mexicana y también a la salida de Fonte de México hacia España.

El arzobispo nunca tuvo simpatía por Itúrbide, entre otras cosas porque en 1818 tuvo que arbitrar, a requerimiento del entonces coronel, en sus desavenencias conyugales, de las que, al parecer, D. ${ }^{a}$ Ramona, la esposa; era víctima de D. Agustín. La postura disidente de Itúrbide a partir de febrero de 1821 aumentó los recelos del arzobispo, que le consideró un insurgente hasta la firma del Tratado de Córdoba el 24 de agosto del mismo año. 
En cambio, Itúrbide intentó reiteradamente atraer a su causa a Fonte y servirse de él para sus designios políticos, a lo que se opuso firmemente el arzobispo. Primeramente trató de que presidiera la Junta Suprema del Imperio prevista en el referido Tratado y luego intentó que le consagrara emperador. Fonte, que había acatado la independencia del Imperio Mexicano porque había sido pactada por la Autoridad legal española, el Virrey O’Donojú, no aceptó nunca a Itúrbide como emperador, dada la dudosa legalidad de su proclamación, se despidió de él, dejó los asuntos eclesiásticos en manos de sus obispos sufragáneos y se volvió a España (7).

Para terminar este breve apunte biográfico diremos que el arzobispo Fonte fue un hombre muy ilustrado, que se esforzó, especialmente durante los años en que fue provisor de la Archidiócesis mexicana; en conocer bien el país y sus habitantes, lo que le permitió informar de muchos extremos al célebre Alexander von Humboldt cuando éste estuvo en México a principios de siglo, por lo que el alemán le citó muy elogiosamente en su Essai politique sur le royaume de la Nouvelle Espagne, publicado en 1825. Su cultura se refleja bien en la redacción de sus memorias (8), que están escritas en un estilo claro y conciso no exento de elegancia, que nos indican que conocía los clásicos y muy bien la historia de la Iglesia y de sus instituciones, y que muestran claramente una preocupación por las necesidades espirituales de sus diocesanos, pero también por las materiales, ya que erigió parroquias y fundó escuelas, administró sacramentos y repartió limosnas e incluso, como se verá más adelante, introdujo la vacuna en gran parte del extenso territorio de la archidiócesis.

Por último, hay también que referirse a su intervención en la política española. Dada su fama de hombre afecto.a la Corona (y posiblemente también debido a su amistad con Calomarde), al pasar por Francia camino de España, en los días en que se estaba produciendo el restablecimiento del poder absoluto de Fernando VII por el ejército francés del Duque de Angulema, parece que el Vizconde de Chateaubriand le quiso implicar en una colaboración política con el monarca absoluto, pero Fonte evadió el compromiso y al llegar a España, después de presentar protocolariamente sus respetos al rey, se retiró a un convento, no volviendo a intervenir en política hasta que a la muerte del rey aceptó de la reina gobernadora María Cristina, el nombramiento de presidente del Consejo de Regencia que ostentó el poder real durante la minoría de edad de Isabel II, y se mostró siempre un decidido partidario de ésta contra el pretendiente carlista, cuya exclusión del trono vetó como miembro del Estamento de Próceres en octubre de 1834 . 
Senador en las Cortes de 1837 y aún después Vicario General de los Ejércitos y de la Armada, D. Pedro José Fonte murió en Madrid.el 11 de junio de 1839.

$$
\text { 米落米 }
$$

Conocido es que la situación sanitaria en América en lo que a la viruela se refiere, era singularmente grave a principios del siglo XIX.

Esta enfermedad era por entonces endémica en todo el continente y atacaba singularmente a las poblaciones indígenas, que eran particularmente sensibles al virus varioloso, todo ello agravado por no haber llegado todavía a América ningún remedio preventivo, con la excepción de la mediocre práctica de la inoculación, consistente en la inducción de la enfermedad, que se suponía que debía adoptar un carácter benigno, mediante pústulas de enfermos de viruela de escasa gravedad.

De vez en cuando, terribles epidemias de viruela diezmaban las poblaciones, especialmente en América meridional, como sucedió con la epidemia de Lima que desde 1800 a 1803 asoló dicha capital.

Por entonces, sin embargo, se conocía ya la vacuna jenneriana y la práctica de la vacunación se había difundido por España, por lo que se habían realizado varios intentos de llevar el remedio a las posesiones españolas de América, intentos que fracasaron por la rápida inactivación del virus vacinal, que no podía resistir tan largo viaje cuando era transportado in vitro. La única posibilidad de llevar la vacuna a América era lograr conservarla «brazo a brazo» durante la larga travesía.

Las gentes cultas de la.metrópoli y de las colonias clamaban porque se hiciera posible el establecimiento en estas últimas del remedio profiláctico que con tan extraordinario éxito se estaba practicando en Europa y, precisamente, debido a las noticias que llegaron del Virreinato de Perú sobre el desarrollo de la última y terrible epidemia de.viruela de Lima, el Ministro de Gracia y Justicia de Carlos IV, don José Antonio Caballero, llegó al convencimiento de la necesidad de emprender una expedición.a este efecto, lo que propuso al rey en 1803.

Acordada por éste la organización de tal expedición, cuyos gastos sufragaría la Corona en su totalidad, se encomendó la redacción del proyecto y su realización al cirujano militar don Francisco Xavier Balmis y Berenguer, que unía a su larga experiencia médica la no pequeña ventaja de haber residido en el Nuevo Mundo durante once años, entre 1781 y 1792, habiendo ejercido allí, entre otros cargos de las Antillas y de Nueva España, 
los de Cirujano Mayor del Hospital del Amor de Dios y del Hospital de San Andrés, ambos en la Capital de Nueva España.

A partir del nombramiento de Balmis se hicieron las cosas con tanta rapidez y eficacia que, presentado el proyecto el 18 de junio de 1803, fue inmediatamente aprobado, y el 20 de noviembre del mismo año la que se había de llamar "Real Expedición Filatrópica», salió del puerto de La Coruña a bordo de la corbeta María Pita, bajo el mando de Balmis y con la ambiciosa tarea de llevar la vacuna a toda la América española y a las posesiones de la Corona española en Asia, la cual, había de tardar tres años en completar su humanitaria misión.

La historia de esta famosa expedición es suficientemente conocida y sobre ella hay bastante escrito; pero quizá la mejor relación sobre ella es la que publicó en 1912 don Julio del Castillo y Domper (9), de la que tomamos y resumimos los datos que se refieren a México.

Sin que por ello se menoscabe el mérito de la expedición de Balmis, es necesario hacer constar que este notorio esfuerzo para la propagación de la vacuna en las posesiones de ultramar había sido precedido por algunas iniciativas particulares, como la del doctor don Francisco Oller, que introdujo con todo éxito la vacuna en Puerto Rico en Noviembre de 1803, con linfa procedente de la isla de Santo Tomás, en las vecinas Islas Vírgenes, por lo que cuando llegó la expedición de Balmis, con los niños inoculados que llevabạn la vacuna «brazo a brazo» a través del Atlántico, hubieron de conformarse sus componentes con colaborar a una mayor y más rápida difusión de la vacuna por toda la isla.

Lo mismo cabe decir de la isla de Cuba, donde, cuando el 26 de mayo de 1804 llegó la expedición, la vacuna ya se había implantado, gracias a la competencia y a la actividad del doctor don Tomás Romay, quien después de haber intentado infructuosamente por varias veces la introducción de la vacuna en la isla, pudo al fin hacerlo con todo éxito a partir de la linfa proporcionada por un niño y dos muchachas procedentes de Puerto:Rico, que habían sido allí vacunados y que llegaron a La Habana el 10 de febrero de 1804.

También en México se habían realizado voluntariosos esfuerzos; unos con más. fortuna que otros, para introducir la vacuna, antes de la llegada de la expedición de Balmis.

El virrey don Joseph de Iturrigaray, recién nombrado y al poner pie por primera vez en el territorio mexicano por el puerto de Veracruz, se propuso ya la introducción de la vacuna en su virreinato y a este efecto dispuso que le acompañara a la capital el médico de la Real Armada don Alexandro García Arboleya, llevando con él la vacuna "en cristales", con la cual, inmedia- 
tamente de su llegada a la misma el 3 de marzo de 1803, comenzó a practicar la vacunación; desgraciadamente, el virus estaba ya inactivado, por lo que el intento de difundir la beneficiosa práctica resultó fallido. Vanos fueron también los esfuerzos que por orden del virrey se hicieron para encontrar entre el ganado vacuno del país alguna res que padeciera el cow-pox y que, por consiguiente, pudiera ser utilizada como fuente de nueva vacuna, pero al final no resultaron estériles los empeños de Arboleya. En efecto, el año siguiente se organizó en La Habana una operación con la colaboración de la marina de guerra, destinada a llevar la vacuna desde Cuba al continente y que se desarrolló en esta forma: el Licenciado don Marcos Sánchez Rubio, médico de La Habana con gran experiencia en vacunación, entregó cierta cantidad de vacuna fresca al piloto segundo de la Armada don Joseph Angel de Zumarán, el cual zarpó de Cuba el 3 de abril de 1804 en la fragata $O$, a bordo de la cual no sólo custodió cuidadosamente la linfa, sino que procedió durante la travesía a vacunar con ella, con la colaboración del cirujjano de la fragata don Joseph Pérez Carrillo, a dos marineros; al llegar a Veracruz el día 11, pudo obtenerse de éstos linfa de sus pústulas para que desde el mismo día procediera a vacunar a los veracruzanos el cirujano de esta ciudad, don Florencio Pérez Comoto, comisionado para ello por el Ayuntamiento. Es justo decir que el Ayuntamiento de Veracruz jugó un papel muy importante en esta operación y que se comportó con gran generosidad e inteligencia. Pues no solamente se vacunaron los habitantes de esta ciudad, sino que rápida y eficazmente se envió vacuná, con todo éxito, primero in vitro a la capital, donde la recibió Arboleya; que el 25 de abril empezó a vacunar con buenos resultados; se repitió el envío de vacuna a la Capital, pero ya esta vez en el brazo de varios recién vacunados de Veracruz, que llegaron a México el día 30 y sirvieron para seguir vacunando a más capitalinos; finalmente, a Campeche, a donde marchó desde Veracruz y a expensas de su Ayuntamiento, el cirujano de la Armada don Miguel Joseph Monzón, quien embarcó en él a cierto número de jóvenes veracruzanos a los que vacunó durante la travesía para mantener el virus en actividad.

También desde Veracruz, y antes del arribo de Balmis, llegó el 21 de mayo a Chihuahua un lote de vacuna in vitro, solicitada por el brigadier don Nemesio Salcedo, comandante general de las Provincias Interiores de la Nueva España, el cual planeó y llevó a cabo con el personal médico militar a sus órdenes una operación de vacunación de gran eficacia por toda la provincia de Nueva Vizcaya.

La expedición de Balmis abandonó la isla de Cuba él 18 de junio de 1804 y se dirigió a México, arribando al puerto de Sisal, en la península yu- 
cateca, el 25 del mismo mes, dirigiéndose seguidamente hacia Mérida, a donde llegó el 28. Inmediatamente, Balmis y sus colaboradores se dispusieron a realizar su tarea, la cual resultó muy facilitada porque ya se había iniciado ésta unas semanas antes con el virus procedente de Veracruz; vía Campeche, como se ha dicho más arriba. En vista de ello; Balmis dejó en Yucatán a sus dos ayudantes Gutiérrez y Pastor para que fueran vacunando por todo el territorio hasta llegar a Guatemala y se embarcó el día 19 de julio hacia Veracruz, a donde llegó cuatro días después, el 24. De allí, marchó Balmis a la capital, donde en virtud de lo ordenado por el Gobierno de España y de acuerdo con el virrey, estableció la Junta Central de Vacuna y dispuso las vacunaciones correspondientes, que empezaron en la capital los días 27 y 28 de julio de 1804, tres meses después de las que se iniciaron con el virus procedente de Veracruz.

Una vez establecida la vacuna en la capital, desde aquí la difundieron Balmis y sus colaboradores por las ciudades más importantes de Nueva España, de donde irradiaba a las comarcas colindantes. Así consta que llegó a Guadalajara el 17 de agosto y de allí a Guanajuato el 24; el 20 de septiem: bre, la expedición llegó a Puebla y de allí, seguidamente, a Cholula. Aproximadamente por las mismas fechas se estaba vacunando en Oaxaca y el 1 de diciembre Balmis comenzaba su campaña de Zacatecas, de donde se organizó una expedición para llevar el virus a San Luis Potosí. Por el mismo rumbo y algo después llegó la vacuna hasta las lejanas provincias de Sonora y Sinaloa.

La ứtima etapa de la expedición fue Acapulco, de donde Balmis salió rumbo a Filipinas en la nao San Fernando de Magallanes el 7 de septiembre de 1805, para llegar a proseguir su extraordinaria labor no sólo en Filipinas sino hasta en la colonia portuguesa de Macao (de donde la linfa traída por Balmis llegó a pasar a la China). Digamos para terminar que, una vez realizada su labor en Manila y en otros puntos del archipiélago filipino y en Macao, llegó Balmis a Lisboa el 14 de agosto de 1806 y unos días después a Madrid, donde fue recibido por el rey el 7. de septiembre del mismo año.

No todas las autoridades de Nueva España colaboraron con Balmis con el entusiasmo que la ejemplar empresa merecía, empezando por el virrey, que tanto interés había mostrado por la introducción de la vacuna cuando él se sintió protagonista; ahora, en cambio, no prestó demasiada colaboración a Balmis e incluso puso tantos inconvenientes para facilitarle el buque que había de conducirlo a las Islas Filipinas que tuvo que ser amonestado por la Corona. Pero también es cierto que otras muchas autoridades le ayudaron con todas sus fuerzas, como consta del Gobernador de Mérida o de 
los Obispos de Puebla y de Oaxaca, que recibieron a los expedicionarios con grandes fiestas y ceremonias y poniendo a su disposición toda clase de medios materiales y su poderosa influencia, como hizo especialmente el último de los citados, que mandó a todos los curas de su diócesis que prestasen la máxima colaboración a los vacunadores e incluso que ellos personalmente se instruyesen y actuasen como tales, con la eficacia que se puede suponer.

En general, las gentes del pueblo no fueron tan entusiastas y al fervor de los primeros días sucedió luego la apatía, por lo que no es de extrañar que al cabo de poco tiempo ya no se vacunaba en México o se hacía muy poco.

Conocido por Balmis en la península que en México había decaído mucha la vacuna, se ofreció el 30 de noviembre de 1809 a la Junta Central Gubernativa del Reino radicada en Sevilla (que gobernaba en ausencia del rey) para volver a Nueva España para implantar de nuevo la vacunación, esta vez con el intento añadido de realizar una investigación en las vacas indígenas para hallar en ellas el cow:pox, lo que garantizaría la obtención de vacuna fresca con mayor facilidad. A pesar de que España sufría las calamitosas consecuencias de la invasión napoléonica, obtuvo Balmis la correspondiente autorización y a primeros de abril de 1810 desembarcó en Veracruz, marchando enseguida a la capital y de allí a recorrer las haciendas de diversas comarcas en busca de reses de las que obtener la vacuna. Esta labor le llevó dos meses escasos, pues a fines de mayo se hallaba ya de regreso a la capital, no sólo sin haber obtenido la preciada linfa antivariólica de las vacas, sino también después de correr serios riesgos al recorrer un país dominado por los insurrectos, que le hicieron temer por su vida, especialmente en Michoacán.

Así que Balmis se dedicó a reorganizar las Juntas de Vacunación y dar nuevo impulso en la capital y en las grandes ciudades a la vacunación de las poblaciones, esta vez con la mejor colaboración del virrey don Francisco Xavier de Venègas que, a pesar de sus preocupaciones políticas del momento, no escatimó su ayuda a Balmis. Para dar una base legal a la operación vacunadora, redactó Balmis un Reglamento de Orden de S. M. para que se propague y perpetúe la. Vacuna en Nueva España que aprobó Venegas y que se imprimió en México el 10 de octubre de 1810, el cual consta de 18 artículos en los que se regulan muy cuidadosamente las circunstancias en que las vacunaciones deben practicarse. A mayor abundamiento, el virrey Venegas presidió en persona acompañado de las demás autoridades el solemne acto con que el 22 de diciembre del mismo año se vacunó a los pri- 
meros 172 niños en el Ayuntamiento de la capital. La estancia de Balmis duró esta vez hasta últimos de 1812, fecha en que volvió a España, desembarcando en Cádiz en febrero de 1813.

$$
\text { 米米 }
$$

Si la situación de la vacuna no era muy satisfactoria en 1810 y había sido necesario el segundo viaje de Balmis para dar nuevo impulso a la decaída vacunación, podemos imaginar la situación sanitaria de México a este respecto cuando Fonte accedió al gobierno de la Archidiócesis en 1815, con la insurrección independentista enseñoreando el país y las autoridades españolas preocupadas más que nada por la situación política y social y poco por las enfermedades de sus habitantes.

La vacuna se había introducido en España el 3 de diciembre de 1800, día en que el doctor don Francisco Piguillem vacunó a cuatro niños de la localidad catalana de Puigcerdá, cerca de Francia, de cuya capital se había importado el virus; el doctor Piguillem continuó propagando la vacuna entre las personas de la comarca y pronto el tratamiento se difundió por toda España, de modo que en abril de 1801 se vacunaba ya en Aranjuez y en Madrid y poco después también en muchos lugares de la península (10).

Como Fonte se embarcó rumbo a México a últimos de 1803, lo más probable es que, como hombre culto que era, supiese ya de los beneficios de la vacuna y aún que estuviese ya vacunado en España. Si no fue así, lo más seguro es que se hiciese vacunar en México en 1804, cuando llegó a la capital la expedición de Balmis.

Pero, sea como fuere, lo cierto es que a Fonte le preocupó el tema de la viruela y su prevención, pues en cuanto recayó sobre el la responsabilidad del Arzobispado se ocupó muy personalmente de este tema.

Nos cuenta el Arzobispo en sus memorias (11) que al hacerse cargo de la Archidiócesis tuvo «noticias bastante tristes del desarreglo que habían ocasionado las circunstancias políticas en el estado formal y material de las parroquias», lo que exigía en primer lugar que procediese a la provisión de los curatos vacantes y a la erección de las vicarías foráneas, y en segundo, su visita personal a la diócesis.

Llevado a cabo lo primero y puestos en orden los asuntos administrativos y económicos de su Casa, se dispuso a realizar la tan necesaria visita pastoral. Puesto a elegir entre las dos regiones más distantes de la capital para su visita, a saber, "la costa del mar del Sur o la del seno mejicano», se decidió por esta última, la más lejana y abandonada, y optó «por visitar 
primeramente la costa de Tampico y al mismo tiempo la Huasteca Alta, Sierras de Metztitlán y Llanos de Pachuca».

La visita fue larga y muy fructífera desde varios puntos de vista. El Arzobispo salió de la capital el 15 de noviembre de 1819 y regresó el 23 de febrero de 1820, habiendo recorrido «en varias direcciones más de 400 leguas: 28 por agua, 50 en coche y las restantes en mulas prácticas de.la Sierra y en caballo por las Huastecas».

La sola mención de estos tiempos y distancias nos puede dar una idea de las dificultades e incomodidades del viaje, pero hay:que decir, además, que todos los gastos de la visita, que fueron muchos, corrieron a cargo de la silla metropolitana, y esto lo manifiesta Fonte con toda claridad con las siguientes palabras: «Me propuse no ser gravoso a los pueblos. Y para ello me previne de todos los artículos, cuya adquisición pudiera ocasionar desembolso a los curas, al paso que les admití el obsequio de aves y carnes que tenían abundantes y baratas en sus propias casas. No consentí que por ninguno de familia, ni a título de derechos, se recibiese dinero alguno. Yo señalé duplicado sueldo a todos mis familiares y criados que me acompañasen en la visita. Y para que mis sucesores no se creyesen perjudicados, mandé poner en los libros visitados esta expresión: sin derechos por esta vez». Se hace patente en estas líneas la generosidad del Arzobispo de la que quiso dar muestras de eșta visita, a cuyo coste hay que añadir, como se verá, los gastos ocasionados por la vacunación.

Fonte era un hombre que sentía por igual las necesidades espirituales y las materiales de sus diocesanos. El mismo dice explícitamente que «merecen ser detallados» los dos objetivos principales de la visita: «1..$^{\circ}$. El medio de proveer de ministro aquel país de la Sierra y la Huasteca, tạn despoblado, distante y enfermizo. 2. ${ }^{\circ}$ Remediar la calamidad con que eran afligidos algunas veces por la viruela natural, no aprovechando el descubrimiento de la vacuna que a tanta costa envió S. M. a Nueva España».

Pero el Arzobispo menciona otros muchos resultados más de su visita; de los que con fundamento se siente orgulloșo, y entre ellos entresaco unos cuantos: la confirmación de 32.811 personas, corregir la conducta de algunos ministros «sin estrépito ni escándalo», reconciliar a los que vivían enemistados públicamente, remitir ornamentos a algunas iglesias pobres, fomentar las escuelas y, por último, «dejar alguna limosna en cada pueblo y no sacar dinero de ninguno».

En las memorias de. Fonte no se detalla el itinerario seguido en la visita y sólo dice que ésta comenzó por Calnali y que luego estuvo en Huejutla y en Tampico, donde se embarcó por el río Moctezuma en una travesía de 25 
horas en compañía del obispo de Monterrey hasta Pánuco, y que luego volvió por Pachuca a México, habiendo recorrido muy penosamente. «la Sierra grande, las Llanuras enfermizas y la Costa peligrosa».

El Arzobispo planeó con todo cuidado la visita, pero especialmente la operación de difusión de la vacuna. Comenzó por informarse por «los curas y otras personas celosas» de "los estragos causados por las viruelas y la necesidad de aprovechar la vacuna», y sus informadores le dieron cuenta de «los obstáculos que habían hecho infructuosas las providencias dictadas por el Gobierno" en la Sierra y en las Huastecas Alta y Baja. "Consistían éstas en repugnancia de los indios; en desavenencias de los subdelegados de la autoridad civil y los curas; en falta de fondos para algunos precisos gastos, y en ignorancia de los sujetos, que hubiesen de practicar la operación, porque se debe suponer que en las 130 leguas que median entre Tampico y Méjico solamente en Tulancingo y Huejutla había facultativios del arte de curar».

El Arzobispo no se arredró ante este cúmulo de dificultades, siendo como era enérgico y voluntarioso y habiendo puesto tanta ilusión en la empresa, lo que se pone de manifiesto cuando afirma con cierto orgullo: «Me propuse vencer todos estos obstáculos y lo conseguí».

Para ello empezó por buscar unos colaboradores fieles que le auxiliasen en la labor y de ello encargó «a dos Vicarios foráneos, a algunos curas y a algunas personas de autoridad e influjo", comisionando para su coordinación al Vicario foráneo de la Sierra doctor don Manuel Villaverde, el cual se hizo cargo de los fondos previstos para sufragar los gastos, todos ellos, como se ha dicho, a cargo del Arzobispo.

Después hizo venir de México «un joven facultativo que fuese inteligente para conducir la vacuna desde la capital, transmitiéndola sucesivamente a niños de las parroquias del tránsito", asegurando así la llegada de la vacuna «brazo a brazo» hasta el interior de las Huastecas.

La operación se desarrolló con éxito, aunque no sin dificultades. El Arzobispo tuvo que proveer abundantes fondos para "premios a los padres y niños dóciles», y el facultativo, al que Fonte le abonó todos los gastos de viaje y una «mesada aventajada», es decir, unos lucidos emolumentos, y que se encargaba no sólo de practicar la vacunación, sino también de «instruir a otras personas en el modo sencillo de practicar esta operación», no pudo'resistir la insalubridad del clima de aquellas regiones y a los dos meses enfermó y murió de resultas de la enfermedad, como enfermaron cinco de los seis misioneros que acompañaban al Arzobispo y cuatro de los indios de su séquito. De resultas del fallecimiento del facultativo, tuvo Fonte 
que contratar a otro que lo sustituyese y, además, señaló a la madre del fallecido «una limosna mensual».

Es una lástima que no conozcamos las cifras de los vacunados en esta ambiciosa operación sanitaria, porque el Arzobispo se limita a decir en sus memorias que «se consiguió vacunar muchos miles de personas en las Sierras y Huasteca», aunque sabemos que todo lo anotó cuidadosamente y que las cifras se consignaron "en los certificados de los curas", que se depositaron en la Secretaría del Arzobispo. Con respecto a esto hay que decir que el Vicario foráneo señor Vịllaverde quería publicar los resultados y que esto no se hizo por expresa voluntad de Fonte, que aduce para ello una razón política que me parece interesante y curioso consignar.

Por aquellas fechas ("habiendo libertad de imprenta», precisa el Arzobispo) se publicó en el periódico de México El Noticiario un artículo firmado por un "anagrama anónimo» en el que se criticaba al gobierno de México por no haber propagado la vacuna por las Sierras. Añade Fonte que "esto era una falsedad notoria, pues acababa de hacerse a mis expensas aquella expedición»; pudo saber el Arzobispo que el malévolo articulista «era un cura a quien se habían pasado órdenes severas para que en su parroquia coadyuvase a los deseos de sus feligreses, que notaban frialdad de su parte, y de aquí resultó que no aparecían vacunados en tanto número como en otras parroquias menos dilatadas». Sospechó, pues, el Arzobispo que el cura en cuestión quería provocarle para que lo desmintiera $y$, con sagacidad y prudencia, para no verse envuelto en una polémica periodística («entrar en la palestra periódica», dice él), no sólo no contestó en la prensa sino ni siquiera publicó las cifras de su campaña.

Aparte de las penalidades del viaje y de los disgustos y contrariedades que inevitablemente tuvo que padecer, el Arzobispo Fonte obtuvo grandes satisfacciones del viaje. No fue la menor el conocimiento directo que hizo de los indios huastecas, a los que desde entonces mostró una simpatía sin límites que no se recató en mostrar ante los canónigos y el virrey que pasaron por su casa a saludarle y felicitarle por su feliz regreso de la larga y laboriosa expedición; a los cuales, según afirma Fonte, «más le sorprendía el regocijo con que yo manifestaba mi aprecio de las ovejas de la Sierra y Huasteca y mis designios de mejorar su suerte». Aquí se refiere el Arzobispo a todos los indios que poblaban la parte de su diócesis que acababa de visitar, pero que su mayor simpatía estaba por los huastecas se muestra en las siguientes líneas: "Por manera que la Sierra presenta un país donde la raza de indios se conserva más pura, y la Huasteca en su generalidad también los conserva; pero aquellos son mejicanos y los de ésta huastecos, que 
nunca pudo someter el cetro de Moctezuma», palabras en las que se puede percibir que apunta, además del afecto, un tanto de admiración.

Fonte termina de escribir sus memorias el 8 de diciembre de 1829, casi diez años después de esta larga y fructífera visita a sus diocesanos los más necesitados. Sin embargo, persiste aun en su recuerdo la huella que dejaron en él estos huastecas, cuya lengua le interesó hasta el punto que a su paso por París cuando regresaba a España en 1823, llevaba en su equipaje una gramática huasteca que regaló a su amigo el Barón Alexander von Humboldt (12), gramática que sin duda había estudiado el Arzobispo, que en otro párrafo de sus memorias dice que «el idioma huasteco... no es difícil de aprender».

\section{NOTAS}

(1) GarCía AlCón, F. (1960). «Turolenses ilustres. El Arzobispo Fonte». Teruel, 23: 143-187.

MarTínez ORTIZ, J. (1962). «Turolenses en Indias». Teruel, 28: 60-142.

Martínez OrTiz, J. (1981). «Memorias y documentos de Pedro José Fonte, último Arzobispo español de Méjico (1915-1823)». Prólogo de J. M. Cuenca Toribio. Teruel, 65: 5-167.

FERNÁNDEZ-Galiano, D. (1988): "Una nota sobre el Arzobispo Fonte». Teruel, 79 (II).

(2) Es sabido que durante la permanencia de Fernando VII en Valençay, cautivo de Napoléon, se estableció en España en 1810 una Regencia compuesta de cinco miembros que asumió todas las competencias de la Corona, entre ellas las que aquélla poseía sobre la jerarquía eclesiástica.

(3) El convoy era muy numeroso y se componía, según nos cuenta el Arzobispo, de 60 mulas de carga, 62 coches, 400 pasajeros, tres millones de pesos y otros artículos; y estaba escoltado por 30 hombres.

(4) Alamán, L. (1849-1852). Historia de Méjico desde los primeros movimientos que prepararon la independencia hasta la época presente. Méjico, 5 volúmenes. La alusión a Calomarde, a la sazón Oficial Mayor del Ministerio de Gracia y Justicia, aparece en el tomo IV, pág. 249.

(5) Véase el capítulo $8 .^{\circ}$ de las Memorias del Arzobispo en J. MarTínez Ortiz (1981).

(6) Documento n. ${ }^{\circ} 19$ en J. Martínez Ortiz (1981).

(7) El regreso a España lo hizo Fonte muy despacio, despidiéndose previamente de Itúrbide y haciendo de paso una larga visita pastoral por toda su diócesis que terminó al embarcarse el 2 de febrero de 1823 en Tampico. Véase D. FernándeZ-Galiano, op. cit. .

(8) Martínez OrTiz, J. (1981)

(9) Castillo y Domper, J. Del (1912). Real Expedición Filatrópica para propagar la Vacuna en América y Asia (1803...) y Progresos de la Vacunación en nuestra Península en los primeros años que siguieron al descubrimiento de Jenner. Madrid (Imprenta de Ricardo F. de Rojas).

(10) Castillo y Domper, J. del (1912).

(11) Todo lo que aparece a continuación entrecomillado son párrafos de las memorias de Fonte, MARTínEZ ORTIZ, J. (1981).

(12) Fernández-Galiano, D. (1988). 


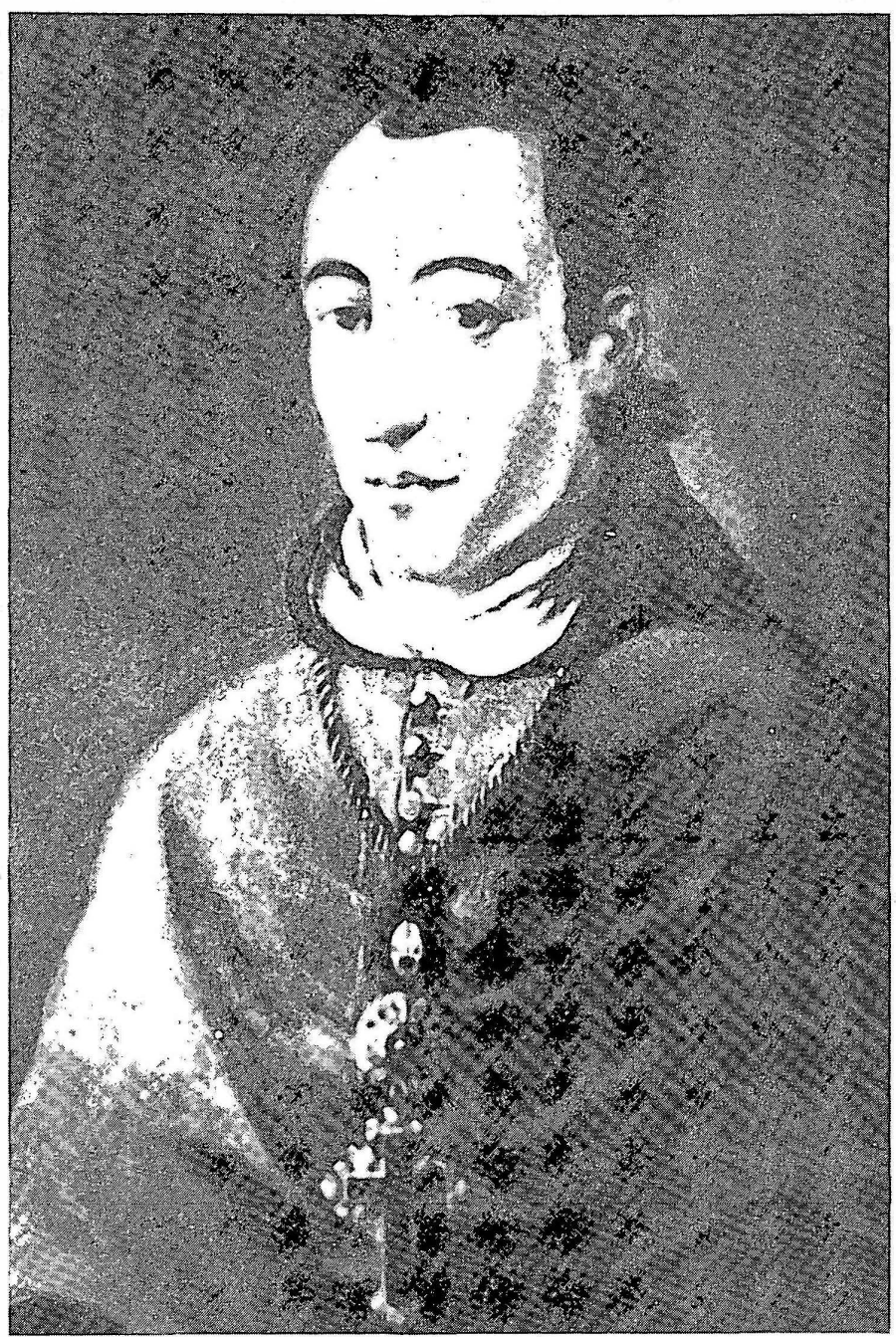

Figura 1

Retrato de D. Pedro José Fonte Hernández, Arzobispo de México desde 1815 a 1823 (Reproducido con autorización del Instituto de Estudios Turolenses. Teruel). 


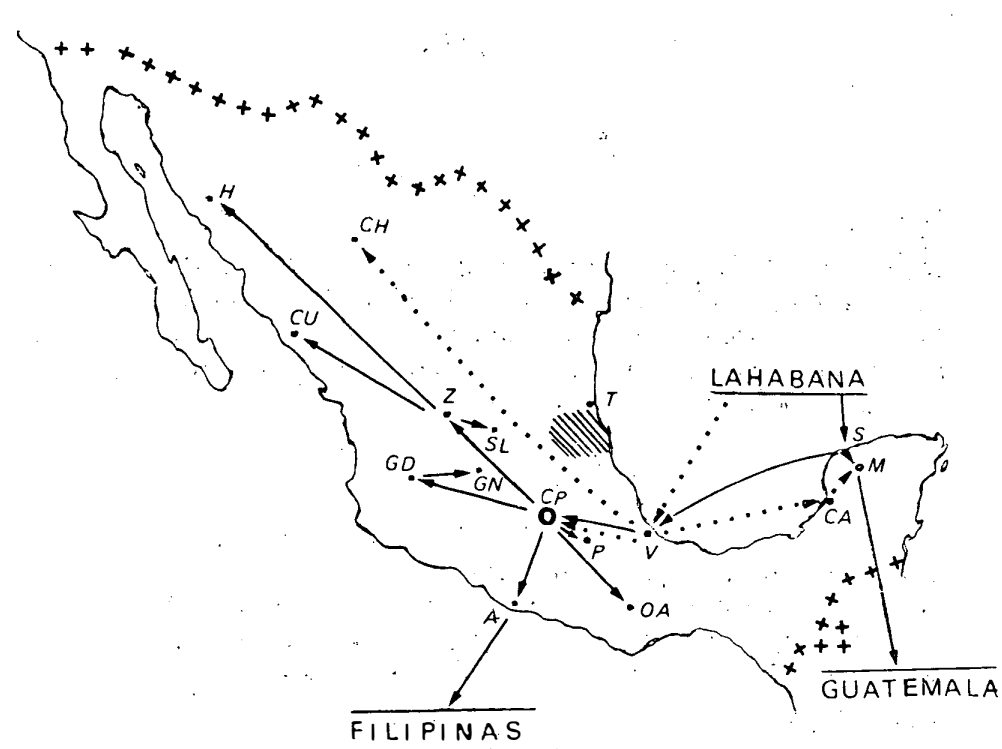

Figura 2

Rutas principales de introducción de la vacuna antivariólica en México a principios del siglo XIX. Las línea de puntos muestras la difusión de la vacuna a partir de la linfa llevada a Veracruz por la fragata $O$; las líneas contínuas señalan las rutas seguidas por Balmis y sus colaboradores. La parte sombreada indica la región por la que el Arzobispo Fonte introdujo la vacuna.

$A$, Acapulco; $C A$, Campeche; $C H$, Chihuahua; $C P$, Capital; $C U$, Culiacán; $G D$, Guadalajara; $G N$, Guanajuato; $H$, Hermosillo; $M$, Mérida; $O A$, Oaxaca; $P$, Puebla; $S$, Sisal; $S L$, San Luis Potosí; $T$, Tampico; $V$, Veracruz; $Z$, Zacatecas.

Asclepio-I-1992 
REGLAMENTO DE ORDEN DE S. M.

\author{
para que se propague y perpetúe la Vacuna \\ en Nueva España.
}

\begin{abstract}
Art. 1.0
E de propagar y perpetuar la paña, estará baxo la inmediata proteccion de los Intendentes de Provincia ó Gobernadores, auxîliados de dos Facultativos que se nombraran para executar las operaciones, y dirigir esta nueva práctica baxo las prevenciones siguientes.
\end{abstract}

2.

Cada Intendente ó Gobernador elegirá uta pieża decente y cómoda de su alojamiento, á donde concurra el público á vacunarse gratuitamente el dia que corresponda cada semana $y$ que señalen los Facultativos, el qual se anunciará con anticipa: cion por carteles en los parages públicos acostumbrados.

\title{
3 .
}

El acto de vacunacion pública, la autorizará con su presencia el Intendente ö Gobernador, que mandará observar el buen órden y decoro que es debido á un acto tan benéfico, al que asistiran precisamente los dos Profesores comisionados, para exâminar prolijamente el curso que ha seguido la vacuna ea su desarrollo, y anotar en un libro todas las particularidades dignas de atencion, y que merezcan darse al público á su debido tiernpo, con lo que se llegará á formar un euerpo de Dôs trina de la vacuna en América.

Figura. 3

Primera página del Reglamento editado por Balmis en la capital de México en 1820 (Ejemplar de la biblioteca de la Real Academia Nacional de Medicina de Madrid). 